\title{
Goodbye and thanks again!
}

Jennifer Richard

Editor

Well, this is it for me, my last column as Editor of Partnership. I must say it is bittersweet, but after mulling it over for the last six months or so, I do believe it is the right time for me. I suppose some of the bitter-part could be the January Blahs. They are particularly acute when still trying to get a fall issue published. It seems that it has been my habit over these columns to update the readers on the comings and goings of the editors, thank lots of people for lots of great things and maybe provide some food for thought or dispense a little advice, and so in my final column I think I have just a little bit left in me, so here goes.

As the founding editor of this journal, I must say I am extremely proud of it. The journal has grown in its readership, its content continues to improve and it reaches more and more people in some capacity or another all the time. Articles are being cited; databases are indexing and abstracting the work, including resources such as Google Scholar; professional blogs pick up our articles and announcements and stats continue to climb. A Google search for the journal name results in tens of thousands of references to it, including citations from new information providers I never knew existed. As librarians, whose strongest belief is in access for all, we love that our work, our efforts get disseminated. We write, not to make money, but to share and build on our services, programmes and ideas, and to increase accessibility to our collections, our expertise, and our facilities. This makes me happy and proves that this journal is a success and was well worth the effort everyone has put into it.

For me, it has been one of the highlights of my career. It has connected me with colleagues, professors, librarians, and library staff from Canada and around the world. It has given me opportunities to collaborate with librarians I've never met. I have emailed, sought advice from, and sat on committees with, editors of some very prestigious journals and it has allowed me to learn a tremendous amount about open access publishing, creative commons licensing and even about myself. In a profession where there are an abundance of ideas and often never time to see them to fruition, this initiative allowed me to participate in turning a really great idea into a really useful, scholarly tool for the Canadian library community.

The one part of writing this column l'll probably miss the most is the ability to express a thought, one that usually comes to me in the shower or in the middle of the night, to the world. My latest parting advice is to find balance in your work and volunteer commitments. We are all often pressured to accept extra work that we are hesitant about, but through some kind of sense of duty, guilt or need for recognition (or promotion) we take on things that our hearts aren't really in. Balance is so important in our lives, I would say I'm a bit of a pot calling out a kettle with this advice, or at least l've felt that way at times. But alas, it's easier to give advice than take it, or abide by your own advice so here goes: regardless of where you are in your career, remember to do whatever you do with passion and enthusiasm, not just because someone told you it 
would look good on your resume, and when/if your interest disappears or wanes, you should know it's time to move on or at least take a break. There is never a need to feel guilty, if you've given it your all.

I've thanked them before, but since this is my last column I need to thank EVERYONE again, but particularly: Cynthia Archer, former OLA President and York University Librarian, as this journal was her idea, I just happened to be fortunate enough to be sitting at the same table at that time. Larry Moore, former Executive Director of OLA, he was at that table too. His guidance and support in those early years were crucial and he was inspiring. Wayne Johnston at the University of Guelph for his unending patience with my last minute frantic requests for stats and complaints about the problems with the OJS system - it must be hard to like someone who only ever asks you to fix problems. To Heather Morrison, the first editor of the Theory and Research section, who set the tone for the high standards of peer review we have and to which we will always adhere. Thanks to all those founding editors, some of whom are leaving with me at this time, including Catherine Steeves, University of Guelph, and Catherine Baird, McMaster University. Thanks also to more recent editors, such as Angie Mandeville, University of Alberta who is also moving on. Thanks and good luck to those who are coming aboard and those who are staying, including Ann Smith, Michael Hohner, Rainer Schira, Catherine Jeanjean, Christine Neilson and Leeanne Morrow. Thanks also to all the readers who have written encouraging words each and every time an issue is published.

We are now in the process of selecting new editors, including a new Editor in Chief, to grow and move this journal on to bigger and better things. Unfortunately I can't announce who they will be yet, but I am so impressed with the number and calibre of volunteers and the effort they put into their applications. As a librarian at Acadia for over 13 years now, I have seen my fair number of applications and the effort and time put into these applications for VOLUNTEER positions show how seriously people take these roles. I would also note that the decision was difficult and I was surprised by the number of librarians who now have editorial experience. In the coming months, please welcome these new faces and assist them in continuing the quality of this journal, by peer reviewing, writing book reviews, and continuing to submit top notch articles about what you love to do!

It has truly been an honour. 